\title{
Antibacterial potential of nudibranch-associated bacteria from Saparua and Nusa Laut Islands, Indonesia
}

\author{
RHESI KRISTIANA $^{1}$, MADA TRIANDALA SIBERO ${ }^{2,3}$, MACELLYNE YOHANNA FARISA ${ }^{4}$, \\ DIAH AYUNINGRUM ${ }^{1}$, DIO DIRGANTARA ${ }^{2}$, MUHAMMAD HANAFI ${ }^{5}$, OCKY KARNA RADJASA $^{2}$, \\ AGUS SABDONO $^{2}$, AGUS TRIANTO ${ }^{2, \bullet}$ \\ ${ }^{1}$ Coastal Resources Management, Faculty of Fisheries and Marine Sciences, Universitas Diponegoro. Jl. Prof. H. Soedarto, S.H., Tembalang, Semarang \\ 50275, Central Java, Indonesia \\ ${ }^{2}$ Department of Marine Sciences, Faculty of Fisheries and Marine Sciences, Universitas Diponegoro. J1. Prof. H. Soedarto, S.H., Tembalang, Semarang \\ 50275, Central Java, Indonesia. Tel.: +62-24-7474698, Fax.: +62-24-7474698, •email: agustrianto.undip@gmail.com \\ ${ }_{3}^{3}$ Marine Science Techno Park, Universitas Diponegoro. Teluk Awur Campus, Jl. Undip, Jepara, Central Java, Indonesia \\ ${ }^{4}$ Department of Aquaculture, Faculty of Fisheries and Marine Sciences, Universitas Diponegoro. Tembalang, Semarang 50275, Central Java, Indonesia \\ ${ }^{5}$ Research Center for Chemistry, Indonesian Institute of Sciences. Puspiptek, Serpong, Tangerang Selatan 15314, Banten, Indonesia
}

Manuscript received: 20 May 2019. Revision accepted: 6 June 2019.

\begin{abstract}
Kristiana R, Sibero MT, Farisa MY, Ayuningrum D, Dirgantara D, Hanafi M, Radjasa OK, Sabdono A, Trianto A. 2019. Antibacterial potential of nudibranch-associated bacteria from Saparua and Nusa Laut Islands, Indonesia. Biodiversitas 20: $1811-1819$. Infections caused by multidrug-resistant bacteria are the international health issue that triggers the urgency of finding new antibacterial agents. The aim of this study was to obtain the nudibranchs-associated bacteria that have bioactivity against multidrug-resistant bacteria. A total of 13 species of nudibranch were identified based on morphological characterization. Overlay methods were used for the screening of the isolates bioactivity against six pathogenic multidrug-resistant bacteria. The Minimum Inhibition Concentration (MIC) of the crude extract was evaluated against Methicillin-resistant Staphylococcus aureus (MRSA), Escherichia coli, Bacillus subtilis, Klebsiella pneumonia, Micrococcus luteus, and Extended Spectrum Beta Lactamases E. coli (ESBL) using MTT method. A total of 145 isolates were obtained which eleven of the isolates showed antibacterial activity against the pathogenic bacteria. The MIC te sts showed that the best activity was isolate SM-S-9-15 and SM-N-3-7. The methanolic extract of isolate SM-S-9-15 active to all of the pathogenic bacteria, while the ethyl acetate extract of the isolate SM-N-3-7 active to the E. coli, B. subtilis, K. pneumonia at the concentration of $500 \mu \mathrm{g} / \mathrm{mL}$. According to $16 \mathrm{~S}$ ribosomal RNA gene sequence-based identification, all active isolates belong to Virgibacillus marismortui, V. dokdonensis, Bacillus kochii, Vibrio algynoliticus, and Pseudoalteromonas piscicida.
\end{abstract}

Keywords: Nudibranch, associated-bacteria, Multi-drug Resistant, antibacterial activity

\section{INTRODUCTION}

The rise in the prevalence of multidrug-resistant (MDR) human pathogens has increased the fatal incidence to at least 700,000 deaths annually worldwide (Wang et al. 2019). A pathogenic bacteria may be categorized as MDR if the pathogen is insusceptible to at least one agent in three or more antibiotic classes (Magiorakos et al. 2012; Basak et al. 2016). Several pathogens such as MRSA, E. coli, B. subtilis, K. pneumonia, and M. luteus have been reported as MDR pathogens. Of these, B. subtilis and M. luteus are commonly isolated as nosocomial bacteria, as they cause infections in the hospital (Panghal et al. 2015; Banawas et al. 2018). Between 2001 and 2016, the worldwide incidence of MRSA infections has increased by more than $10 \%$ that has led to the increased difficulty of treatment with currently marketed drugs (Lee et al. 2018). Additionally, Scheuerman et al. (2018) reported that ESBL and $K$. pneumoniae cause high mortality rates in patients with a bloodstream infection. The high number of MDR infections and the few choices in antibiotics to treat them indicates the urgency for exploration of new antibiotic candidates.
Marine invertebrates have been considered as the prospective sources of bioactive compounds (Senthilkumar and Kim 2013; Miller et al. 2018; Vlachou et al. 2018). Among all marine invertebrates, sponges are widely accepted as being the most prolific source of bioactive compounds. Compared to sponges, the Indonesian nudibranch is much less explored, especially concerning bioactive compounds. Nudibranchs, or marine sea slugs, are marine invertebrates that are classified as phylum Mollusca, classed as Gastropods, ordo Nudibranchia (Harris 1973; Arbi 2011; Chavanich et al. 2013). Nudibranch can easily be recognized in nature with its morphological characteristic, namely the slug-like form, absence of an outer shell and the presence of rhinophores that function as its eyes (Arbi 2011). However, several novel compounds have been reported as having been isolated from nudibranch. Namely the 4-isocyano-9amorphene and 10-isocyano-4-amorphene from Phyllidiella pustulosa, P. ocellate (Sim et al. 2018), dendrodoristerol from Dendrodoris fumata (Huong et al. 2019) and finally xidaoisocyanate A and bisformamidokalihinol A from Phyllidiella sp. that feed on a marine sponge Acanthella cavernosa (Wu et al. 2019). 
However, large quantities of nudibranch are required for the production of the bioactive compounds, and direct extraction from nature could be unsustainable for the ecosystem in regards to the function of nudibranch in the marine food web (Ramirez et al. 2017; Cunha et al. 2018; Davis et al. 2018). Therefore, a study of nudibranchassociated bacteria as a source of bioactive compounds is strongly proposed to find their bioactivity against MDR. A study by Calvacanti et al. (2008) reported nudibranch Tambja eliora produces alkaloid tambjamine D as cytotoxic and genotoxic compounds. Riyanti et al. (2009) reported having successfully isolated 27 associated bacteria from Jorunna sp. and Chromodoris sp. Moreover, Böhringer et al. (2017) studied the diversity of nudibranchassociated bacteria from North Sulawesi, Indonesia and the potential of the bacterial isolates as a source of antimicrobial substances which resulted in 35 of 49 isolates with antimicrobial activity dominated by the genus Pseudoalteromonas and Vibrio. Our report aims to isolate the nudibranch-associated bacteria with antibacterial potential against MDR bacteria.

\section{MATERIALS AND METHODS}

\section{Sample collection sites}

Nudibranchs were taken in September 2018 at four sites of Maluku Province, Indonesia (Figure 1): Site 1 (128 33' 9.3" E, $3^{0} 29^{\prime}$ 97.3" S/Saparua Island); Site 2 (128 42' 7.38" E, $3^{0} 25^{\prime}$ 77" S/Saparua Island); Site 3 (128 47' 97.6" E, $3^{0} 38^{\prime} 37.1^{\prime \prime}$ S/Nusa Laut Island); Site 4 (1280 48' 70.9" S, $3^{0} 38$ ' 74.7 E"/Nusa Laut Island). Specimens were stored in zip-lock plastic bags at depth $5-30 \mathrm{~m}$ by scuba diving. Each specimen was collected according to scientific needed for conservation consideration (Marine regulations 2016). All collected specimens were kept in a cool-box for the source of associated bacteria (Hooper 2003, Kang et al. 2013). Underwater photography of each specimen was taken during diving for documentation. The specimens were chosen based on the morphological appearance according to identification book of nudibranch.

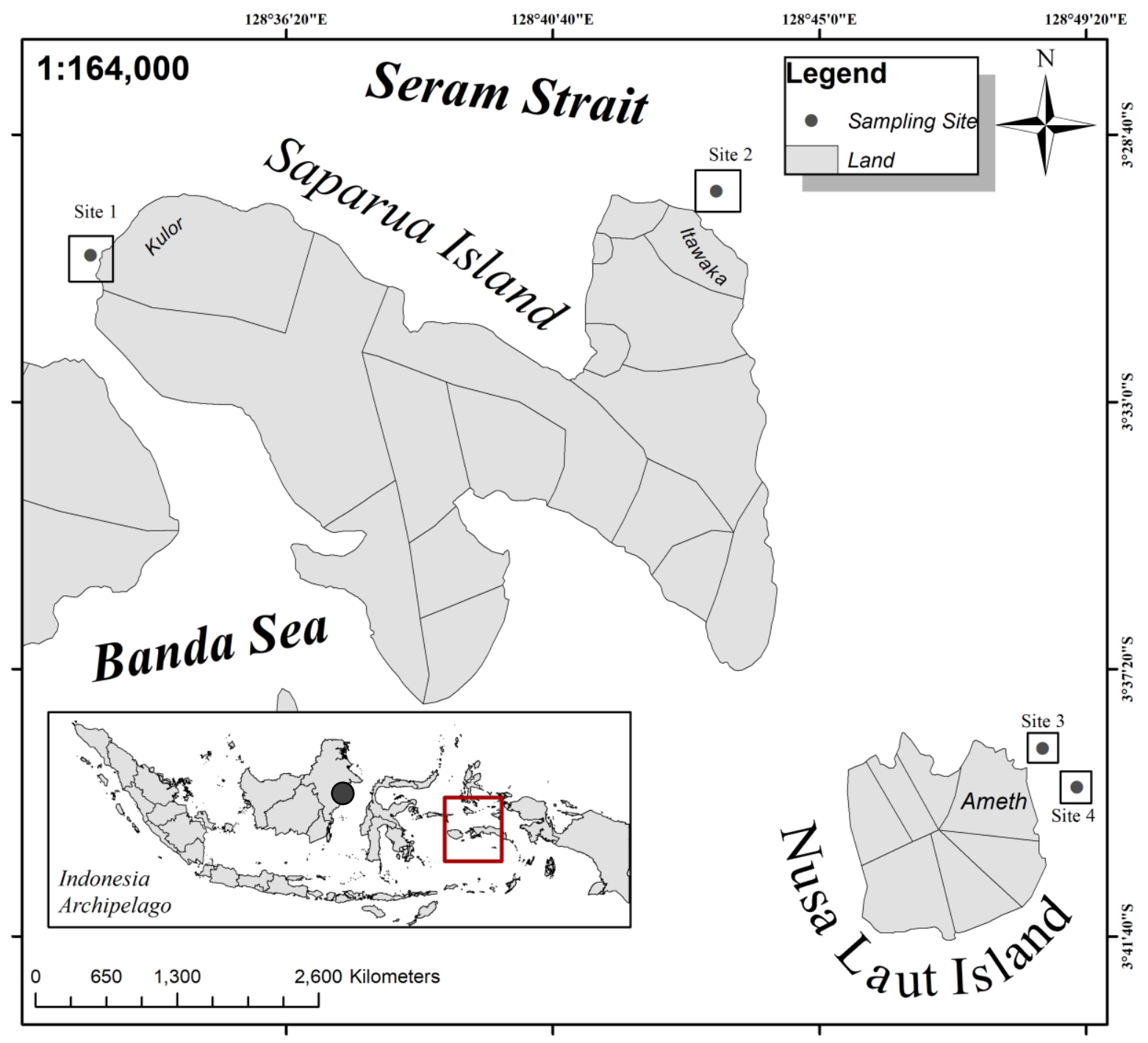

Figure 1. Sampling site in East Indonesian Archipelago. Redline is indicated area sampling. Black circles are indicated specific location. Site one and two are in Saparua Island and site three and four are in Nusa Laut Island, Maluku, Indonesia 


\section{Isolation of nudibranch-associated bacteria}

Specimens were rinsed using sterilized seawater (SSW) to remove impurities. Each specimen was separated into two sections, namely the body and viscera parts, and subsequently smoothly crushed with a sterile mortar and pestle. Bacterial isolation was performed using a dilution method (Gupta et al. 2017). This was done serially from 10${ }^{1}, 10^{-3}$ and $10^{-4}$. Diluted nudibranch fragments were plated on Nutrient Agar (NA) (Oxoid UK). The composition of the NA was as follows: Lab-Lemco $6.10^{-5} \mathrm{~g} / \mathrm{L}$, Yeast Extract $1,3 \cdot 10^{-5} \mathrm{~g} / \mathrm{L}$, Peptone $3 \cdot 10^{-4} \mathrm{~g} / \mathrm{L}$, Sodium Chloride $3.10^{-4} \mathrm{~g} / \mathrm{L}$ and Agar $1.10^{-3} \mathrm{~g} / \mathrm{L}$. The inoculation with bacteria was done with the spread method and incubation lasted for 24 hours at $32^{\circ} \mathrm{C}$. Based on the morphological characteristics, bacterial colonies were separated and purified in sequence onto fresh NA media in order to obtain a pure culture (Ramos 2004; Risan 2017).

\section{Screening of antibacterial activity}

Using the overlay method, the bioactivity of the isolates was screened in the following order against MRSA, E. coli, B. subtilis, K. pneumonia, M. luteus, and ESBL. The isolates were then inoculated onto NA media using a streak method and incubated for 24 hours stored at $32^{\circ} \mathrm{C}$. The MDR bacteria were cultivated in a ten $\mathrm{mL}$ Nutrient Broth (NB) medium. The composition of the NB was $1 \mathrm{~g} / \mathrm{L}$ LabLemco powder, $2 \mathrm{~g} / \mathrm{L}$ yeast, $5 \mathrm{~g} / \mathrm{L}$ peptone, and $5 \mathrm{~g} / \mathrm{L}$ sodium chloride, in 1 liter of SSW. Cultured MDR was then placed in an orbital shaker for 24 hours. The density of the cultured MDR was measured with a 0.5 McFarland standard. The isolates in the NA soft media was mixed with $1 \%$ of the inoculated MDR and incubated for 24 hours at $37^{\circ} \mathrm{C}$ (Muhialdin et al. 2012).

\section{Mass cultured and extraction of crude extract}

The bacterial isolates that showed potential were cultivated in a liquid medium to stimulate the production of antimicrobial compounds. The fresh colony was inoculated in $25 \mathrm{~mL}$ of Zobell broth medium (peptone and yeast) as the starter of mass culture. The isolate was cultured in a $250 \mathrm{~mL}$ flask. The mass cultures were transferred from 250 $\mathrm{mL}$ flasks to one liter Erlenmeyer flasks and incubated in a shaking incubator at $110 \mathrm{rpm}$ and $37^{\circ} \mathrm{C}$ for four days (Radjasa and Sabdono 2003).

Harvesting was done by 15 minutes of centrifugation of cultured bacteria at $8,000 \mathrm{rpm}$ and at $4^{\circ} \mathrm{C}$. The pellet of bacteria was extracted with methanol $(\mathrm{MeOH})$ and the medium was extracted in a separation funnel with ethyl acetate (EtOAc) at a ratio of 2: 1 between solvent and medium, respectively. The solvents ( $\mathrm{MeOH}$ and EtOAc) were evaporated in a rotary evaporator and the mass of each crude extract was calculated. The obtained crude extract was further tested for antibacterial activity.

\section{Antibacterial activity of crude extract}

The bacterial extract was tested against all of six MDR bacteria using 96 well plates with suspended bacteria. The 96 well plates were incubated overnight at $37{ }^{0} \mathrm{C}$ in a shaker at $210 \mathrm{rpm}$ and using MTT (4,5-dimethylthiazol-2yl)-2,5-diphenyltetrazolium bromide) methods as color- based indicators of antibacterial activity. Vancomycin was used as positive control and DMSO (Dimethyl sulfoxide) were used as a negative control (Ayuningrum et al. 2019).

\section{S rRNA gene sequence-based identification of active bacteria of potential isolates}

Identification of potential isolates that have an active response against the MDR pathogens was done using molecular identification. The DNA extraction was carried out using the Chelex method (Walsh et al. 1991) with several modifications that are explained by Sibero et al. (2019a). Selected colonies were inoculated in 50-100 $\mu \mathrm{L}$ $\mathrm{ddH}_{2} \mathrm{O}$ and $1 \mathrm{~mL}$ of $0.5 \%$ saponin in a phosphate buffer solution (PBS) $1 \times$ (stored overnight). The mixture was centrifuged at $12,000 \mathrm{rpm}$ for 10 minutes $(1 \mathrm{rpm}=1 / 60$ $\mathrm{Hz}$ ), after which the supernatant was discarded. Then, 100

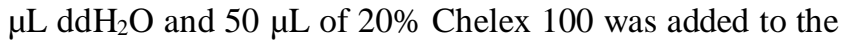
final solution and boiled for ten minutes and vortexed once for five minutes. The mixture was centrifuged at 12,000 rpm for ten minutes and stored at $-20^{\circ} \mathrm{C}$. The bacterial DNA that was used for 16S rRNA gene sequencing was amplified with a polymerase chain reaction (PCR) using the universal primers $27 \mathrm{~F}$ (5'AGAGTTTGATCMTGGCTCAG-3') and 1492R (5'TACGGTTAACCTTG TTACGACTT-3'). The PCR conditions used in this study were in accordance with Ayuningrum et al. (2017), namely as follows. Initial denaturation at $95^{\circ} \mathrm{C}$ for three minutes followed by 30 cycles of denaturation at $95^{\circ} \mathrm{C}$ for one minute per cycle, annealing at $53.9^{\circ} \mathrm{C}$ for one minute, extension at $72^{\circ} \mathrm{C}$ for one minute, and the final extension at $72^{\circ} \mathrm{C}$ for seven minutes. The next step was gel electrophoresis with a voltage of 100 volts for a duration of 30 minutes. The visualization of the PCR product was done using UVIDoc HD5 (UVITEC Cambridge, UK). The amplified isolate was then processed through a DNA sequencer in Genetica Science, Jakarta.

The sequenced isolates were aligned using the MEGA 7.0.26 software package followed by BLAST (Basic Local Alignment Search Tool) analysis to discover bacterial similarities. All aligned nucleotide sequences of potentially anti-pathogenic bacteria have been deposit in the GenBank National Center for Biotechnology Information (NCBI) database under assigned accession numbers shown in Table 2. Phylogenetic tree analyses were conducted with the neighborhood-joining (NJ) tree method described in Kristiana et al (2017). This way, the diversity of antipathogenic bacteria associated with nudibranch was investigated.

\section{RESULTS AND DISCUSSION}

\section{Identification of nudibranch}

Nudibranch can be recognized easily in nature with the morphological characteristic i.e. the slug like-form, absence of outer shell and the presence of rhinophore that has vision function (Arbi 2011). Table 1 and Figure 2. shows the result of nudibranch identification. Numerous studies in Indonesia reported on the diversity of 
nudibranchs from several locations. Bunaken National Park in North Sulawesi is one location that well surveyed. Four surveys by Eisenbarth et al. 2018 documented more than 200 species, which approximate $50 \%$ of the specimens have been identified, and the rest still unknown. In this study, a total of 13 specimens were collected and identified based on the morphological characteristics according to identification book "Nudibranch Behavior" (Behrens et al. 2005).

Table 1 shows the 13 nudibranchs that were collected from the Saparua and Nusa Laut Islands. The nudibranchs were identified as nine different species based on their morphological characteristics. Behrens et al. (2005) and Coleman (2001) stated that morphological identification is commonly applied to identify the nudibranch until the species level because every species has a specific color pattern and formation. C. lochi was the most abundant species at the sampling sites. The several specimens belonging to $C$. lochi were 18-SM-N-3, 18-SM-N-6, 18SM-N-7, 18-SM-N-10, and 18-SM-S-7. Specimen 18-SM$\mathrm{N}-14$ is suggested as $C$. annae because of its blue with darker markings and lack of a mid-dorsal longitudinal line; small black specks within the blue areas (Eisenbarth et al. 2018). At this location, three different species of genus Phyllidiopsis were collected and identified as P. pipeki (18SM-N-2), P. fissurata (18-SM-N-8), and P. krempfi (18SM-S-11). Pavlov and Britayev (2012) stated that the notum of Phyllidiopsis is relatively broad, hard, usually covered by a few short tubercles towards the notal edge and several large conspicuous tubercles medially. The rhinophores are lamellate and the rhinophoral pockets are well defined contractile sheaths with smooth edges. The rudimentary gill cavity encircles the anus (Martynov et al. 2012).
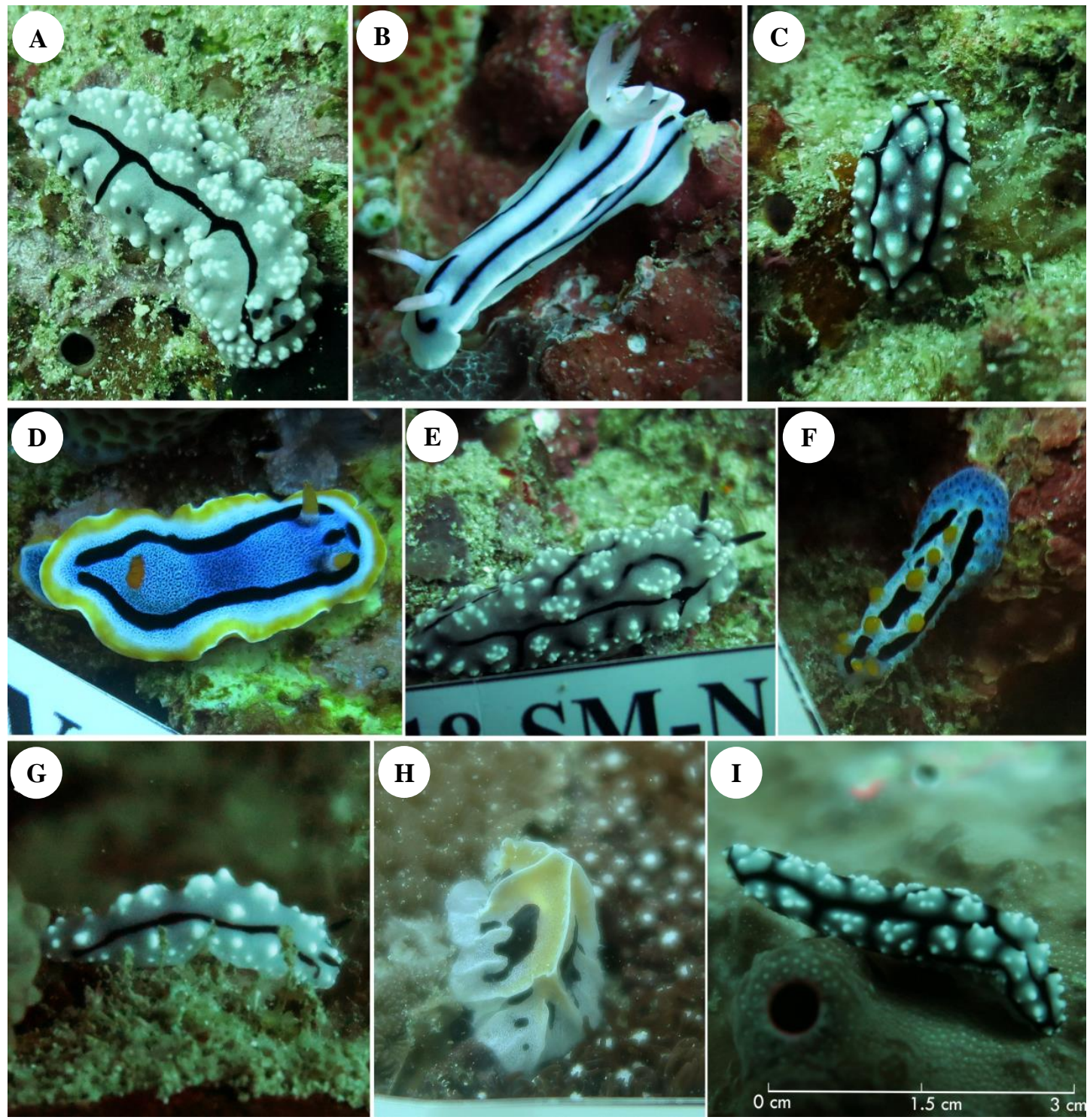

Figure 2. Nudibranchs collected from Saparua and Nusa Laut Islands, Maluku, Indonesia. Note: A. Phyllidiopsis pipeki; B. Chromodoris lochi; C. Phyllidiopsis fissurata; D. Chromodoris annae; E. Phyllidiella pustulosa; F. Phyllidia coelestis; G. Phyllidiopsis krempfi; H. Reticulidia fungia; I. Phyllidiella cooraburrama 
Sample 18-SM-N-2 had two longitudinal black lines that are only present in $P$. pipeki. The presence of the moderately broad and hard notum helps to identify the N-8 as $P$. fissurata, as well as the two main black lines that run laterally and are connected through the middle part of the notum by a few transversal lines. The rhinophores are pinkish anteriorly and black posteriorly. The specific shape and color pattern of P. krempfi existed in sample 18-SM-S11. The two specimens 18-SM-N-19 and 18-SM-S-17 are identified as $P$. pustulosa and $P$. cooraburrama, respectively. The identification of $18-\mathrm{SM}-\mathrm{N}-19$ as $P$. pustulosa was determined by the presence of predominantly black with pink or white tubercles. Specimen 18-SM-S-17 has characteristic pinkish with a network of dorsal black lines is also visible on $P$. cooraburrama. Specimen 18-SM-N-22 belongs to Phyllidia coelestis with the specific characteristics such as blue with black color between the ridges, yellow tubercles, and rhinophores. Furthermore, 18-SM-S-9 was assigned as Reticulidia fungia which has specific characteristics such as the bluish-white mantel with a few broad, smooth, orange ridges and white crests.

The diversity of nudibranch is influenced by food, habitat, coral coverage, evolution, and environment (Korshunova et al. 2017). Generally, nudibranchs eat algae, sponges, hard and soft corals, bryozoa and hydroids (Allen and Steene, 1999). Saparua and Nusa Laut Island are noted as having environmental condition such as temperatures, height waves, foods and substrates that support the diversity of this invertebrate (Mulyadi 2011). Moreover, the presence of sponge in the environment suggests a dominance of $C$. lochi in the sampling sites.

\section{Isolation and screening antibacterial activity}

From the collected nudibranchs specimens, a total of 145 bacterial isolates were obtained. The isolates were tested against six MDR pathogenic bacteria that resulted in 11 active isolates as shown in Table 2.

Table 1. Identification of the collected nudibranch from Saparua Island, Maluku Province, Indonesia

\begin{tabular}{lll}
\hline Sample ID & Proposed species & Key identification* \\
\hline 18-SM-N-2 & Phyllidiopsis pipeki & $\begin{array}{l}\text { The body color is grey with a pinkish hue and two longitudinal black lines; some specimens } \\
\text { with a few black spots or several black rays extending to the edge of the mantle; tubercles large, } \\
\text { single or compound; rhinophores black and pink, with a black line posteriorly. Size: } 4 \text { cm. } \\
\text { Habitat: on the reef flats in 10-20 m depth }\end{array}$
\end{tabular}

18-SM-N-3 Chromodoris lochi The body color is pale blue with a dark blue submarginal band and mid-dorsal line; rhinophores

18-SM-N-6

$18-\mathrm{SM}-\mathrm{N}-7$

18-SM-N-10

$18-\mathrm{SM}-\mathrm{S}-7$

$18-\mathrm{SM}-\mathrm{N}-8$

18-SM-N-14 Chromodoris annae

18-SM-N-19 Phyllidiella pustulosa

18-SM-N-22 Phyllidia coelestis

18-SM-S-11 Phyllidiopsis krempfi

18-SM-S-9 Reticulidia fungia

18-SM-S-17 and gill range from yellow to pink. Size: $3.5 \mathrm{~cm}$. Habitat: on the walls of the fringing and barriers reefs where it feeds on sponges

Phyllidiopsis fissurata Grey with tall, multi-compound pink tubercles; dark grey to black pigment forming lines and deep fissures between the tubercles; rhinophores pink with black posteriorly. On sharp drop-offs and walls. Size: $4.5 \mathrm{~cm}$

Blue with darker markings and lacking a mid-dorsal longitudinal line; small black specks within the blue areas. On open rock walls and reef faces where it feeds on aplysillid spinges in 15-30 m. Size: $4 \mathrm{~cm}$

Highly variable in color pattern, predominantly black with pink or white tubercles; tubercles arrange in small clusters, becoming more separated as the animal grows. In shallow water reefs to deep reef slopes, 5-40 m; one of the most common phyllidiid on Indo-Pacific reefs; the flatworm Pseudoceros imitates mimics this species. Size: $4 \mathrm{~cm}$

Blue with black pigment between the ridges; tubercles and rhinophores yellow; a black line on the foot sole. Probably the most common and widespread species of Phyllidia; in the open on patch reefs or reef faces; egg mass flat. Size: $5 \mathrm{~cm}$

Pink with irregular, black, longitudinal lines that meander between the tubercles; long spicules visible through the translucent pink notum; medial tubercles compound with tips lighter than the body; rhinophores pink, black posteriorly. Crawling on reef flats in 10-15 m. Size: $4 \mathrm{~cm}$

Bluish-white with a few broad, smooth, orange ridges with white crests; black areas between the ridges; mantle margin with a grey-blue line. On reef slopes and walls in 20-40 m. Size: $3.5 \mathrm{~cm}$

Phyllidiella cooraburran $\begin{aligned} & \text { Pinkish with a network on dorsal black lines; very large, isolated dorsal tubercles with broad } \\ & \text { pink bases and elongate multi-compound apices; rhinophores black. On shallow reefs where it } \\ & \text { feeds on orange sponges. Size: } 5 \mathrm{~cm}\end{aligned}$

Note: * The identification based on Behrens and Coleman (2005) 
Table 2. The abundance of nudibranch associated-bacteria

\begin{tabular}{|c|c|c|}
\hline Specimen & $\begin{array}{c}\text { Number } \\
\text { of } \\
\text { associated } \\
\text { bacteria }\end{array}$ & $\begin{array}{l}\text { Prospective active } \\
\text { isolate }\end{array}$ \\
\hline P. pipeki & 12 & SMN-2-2 \\
\hline C. lochi & 10 & SMN-3-1, SMN-3-7, SMN-3-77 \\
\hline C. lochi & 10 & - \\
\hline C. lochi & 12 & - \\
\hline P. fissurata & 13 & - \\
\hline C. lochi & 12 & SMN-10-2, SMN-10-23 \\
\hline C. annae & 15 & SMN-14-13 \\
\hline P. pustulosa & 8 & SMN-19-12 \\
\hline P. coelestis & 8 & SMN-22-13 \\
\hline C. lochi & 13 & - \\
\hline P. krempfi & 12 & - \\
\hline Reticulidia fungia & 9 & SMS-9-15 \\
\hline P. cooraburrama & 11 & SMS-17-9 \\
\hline Total & 145 & 11 isolates \\
\hline
\end{tabular}

Note: - : there is no activity were observed

Table 3. Antibacterial activity of prospective isolates against pathogenic bacteria at concentration $500 \mu \mathrm{g} / \mathrm{mL}$

\begin{tabular}{|c|c|c|c|c|c|c|c|c|c|c|c|c|c|c|}
\hline \multirow[t]{2}{*}{ Isolate } & \multirow{2}{*}{ 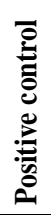 } & \multirow{2}{*}{ 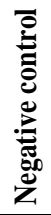 } & \multicolumn{2}{|c|}{ 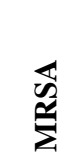 } & \multicolumn{2}{|c|}{$\underset{|c|}{U}$} & \multicolumn{2}{|c|}{$\mathscr{\infty}$} & $\theta$ & \multicolumn{2}{|c|}{$\dot{\Sigma}$} & \multicolumn{3}{|c|}{ 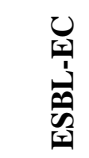 } \\
\hline & & & 1 & 2 & 1 & 2 & 1 & 2 & 12 & 1 & 2 & 1 & & 2 \\
\hline SM-N-19-12 & + & - & - & - & + & - & - & - & - & - & - & - & & - \\
\hline SM-S-17-9 & + & - & - & - & + & - & - & - & - & - & - & - & & - \\
\hline SM-N-22-13 & + & - & - & - & - & - & - & - & - - & - & - & - & & - \\
\hline SM-N-10-23 & + & - & - & - & - & - & - & - & - - & - & - & - & & - \\
\hline SM-N-3-1 & + & - & - & - & + & - & - & - & - - & - & - & - & & - \\
\hline SM-N-14-13 & + & - & - & - & - & - & - & + & - & - & 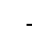 & - & & - \\
\hline SM-N-10-2 & + & - & - & - & - & + & - & - & - & - & - & - & & - \\
\hline SM-N-3-77 & + & - & - & - & - & + & - & - & - & - & 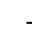 & - & - & - \\
\hline SM-S-9-15 & + & - & + & - & + & - & & - & +- & + & . & $t$ & + & - \\
\hline SM-N-2-2 & + & - & - & - & - & - & - & - & - - & - & . & - & & - \\
\hline SM-N-3-7 & + & - & - & - & - & + & - & + & -+ & - & . & - & - & - \\
\hline
\end{tabular}

Note: $* 1$ : biomass methanol extract, 2 : broth ethyl acetate extract. + : positive reaction, -: negative reaction). Positive control: Vancomycin, negative control: DMSO. Activity screen with following microorganisms; MRSA (Methicillin-Resistant Staphylococcus aureus); EC (Escherichia coli); BS (Bacillus subtilis); KP (Klebsiella pnemoniae); ML (Micrococcus luteus); ESBL-EC (Extended-spectrum beta-lactamases-Escherichia coli).

Examination of the diversity of nudibranch-associated bacteria has rarely been done before. As a predator of other invertebrates such as ascidians, cnidarians, and sponges, the abundance of nudibranch-associated bacteria is influenced by the diversity of the bacteria living in the prey. Schuett and Doepke (2013) found a type of bacterial aggregate in several species of nudibranchs that bear a resemblance to the typical coccoid endobacterial that exists in their prey. In addition, Zhukova and Eliseikina (2012) stated that the feeding behavior of nudibranchs on sponges and tunicate leads to direct microbial transferal from the prey to the nudibranch's tissue. It was suggested that the nudibranch-associated bacteria in this study might have originated from its prey. However, the original associatedmicroorganisms from this invertebrate are poorly understood. Therefore, further study is strongly suggested to confirm the bacteria's origin. As depicted in Table 2, 11 prospective isolates showed antibacterial activity. A previous study of Böhringer et al. (2017) also proved that nudibranch-associated bacteria in Indonesia are active in the production of antibacterial compounds.

\section{Antibacterial activity of the crude extract}

The active isolates were cultured for production of the extract that also be screened against all of the pathogens. The test exhibited that six isolates produced the extract that showed activity against one pathogen, and two isolates produced extract that was active against two pathogens (Table 3.). Methanol and ethyl acetate were used for extraction to provide the polar and less-polar compounds, respectively (Jassbi et al. 2016).

The extract of the isolates SM-S-9-15 and SM-N-3-7 showed broad-spectrum antibacterial activity due to its ability to inhibit more than two pathogenic bacteria. Meanwhile, the isolates that were active against one pathogen were SM-N-19-12, SM-S-17-9, SM-N-10-23, SM-N-14-13; SM-N-10-2, and SM-N-3-77 (see Table 3). The antibacterial property of nudibranch-associated bacterial crude extract has been investigated by Böhringer et al. (2017). They reported that among 49 isolated bacterial strains, 35 isolates $(71.42 \%)$ showed antibiotic activity. They additionally support the notion that nudibranch-associated bacteria is a promising source for antibiotic discovery. Previously, Riyanti et al. (2009) gave a similar result in that a nudibranch-associated actinobacteria, Streptomycetes sp. from Panjang island, Jepara, exhibited antibacterial activity against several MDR bacteria. In this study, only seven $(4.83 \%)$ bacterial crude extracts showed antibacterial activity against MDR bacteria. This number was lower than a previous study by Böhringer et al. (2017). However, Riyanti et al. (2009) specifically looked at the ability of nudibranch-associated bacteria to combat MDR bacteria as opposed to Böhringer et al. (2017) who targeted non-MDR bacteria. Finally, Sibero et al. (2019b) proved that both intra- and extracellular metabolites from marine microorganisms performed antibacterial activity against MDR bacteria.

\section{Diversity of potential bacteria associated nudibranch}

This research reports that host and the specific of bacteria species influenced the potential bacteria as antibacterial activity. There were among others 11 bacterial isolate species (Figure 3) from the genus Bacillus, one species from the genus Pseudoalteromonas, one species from the genus Vibrio and eight species from the genus Virgibacillus. Previous research shows that genus Pseudoalteromonas isolated from marine sponge (Mycale armata) produces red pigments and has antibacterial activity (Feher et al. 2008). Isnansetyo and Kamei (2003), also reported antibacterial activity, namely a new anti- 
MRSA phenolic composition of Pseudoalteromonas, isolated from seawater. Another study of anti-MRSA looked at the potential of symbiotic bacteria from marine organisms such as Tunicata (Fedders et al. 2010), Porifera (Kamei and Isnansetyo 2003), and marine algae (Hentschel et al. 2001). Vibrio sp. is bacteria symbiosis with animal species of Dysilea sp. found in the Indian Ocean. This bacterium produces bioactive ingredients bis (dibromophenyl) ether, which is typically found in Dysilea sp. This also proves that bacteria in this symbiosis obtain secondary metabolisms (Sidharta 2000). Based on literature review, this extension discusses that the bacteria Virgibacillus sp. has potential as a protease producer (Sinsuwan et al. 2010) and antifungal in gray mold disease caused by Botrytis cinerea fungi in strawberry plants (Essghaier et al. 2009).

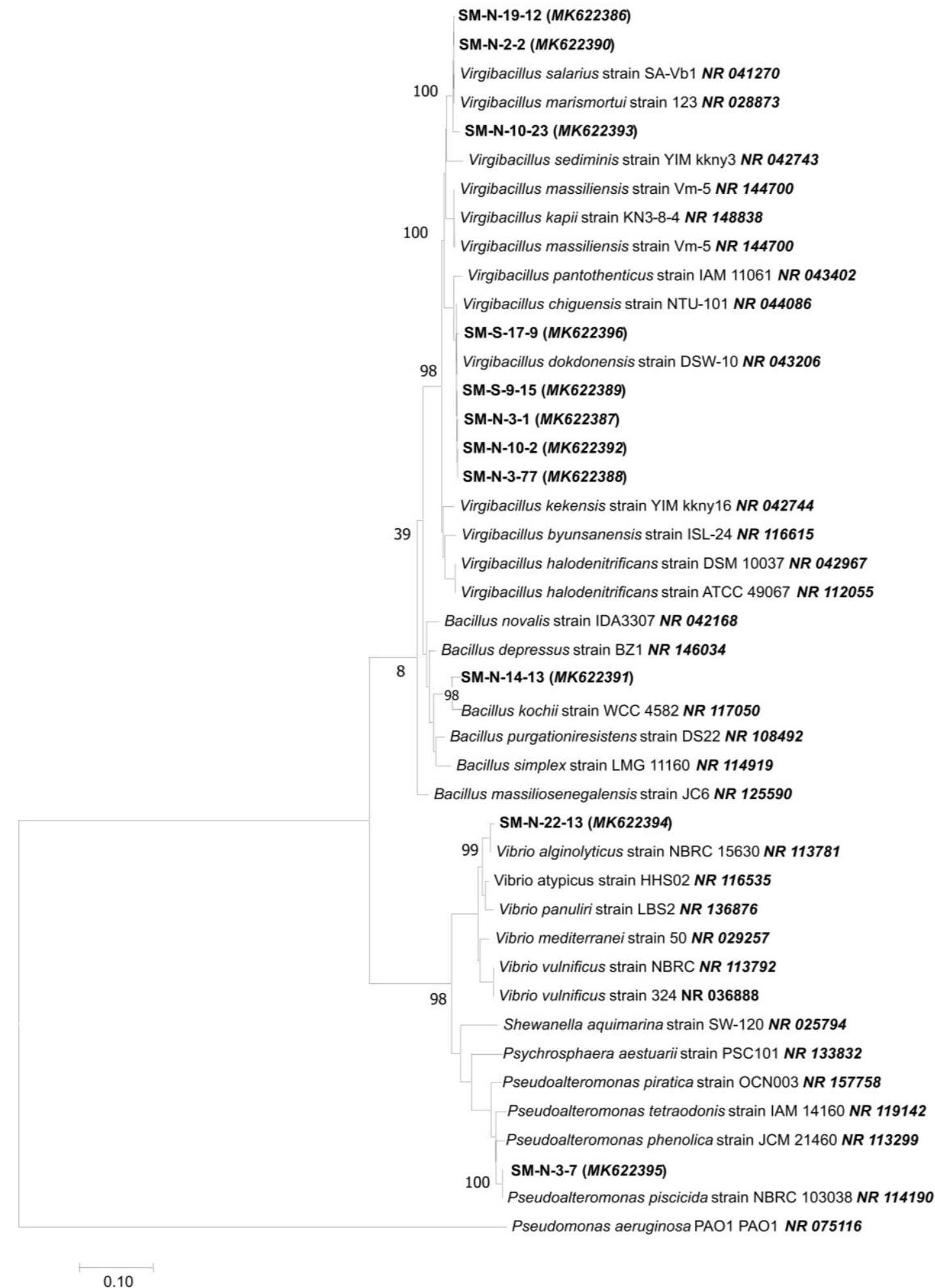

Figure 3. Phylogenetic tree of bacteria associated nudibranch 


\section{ACKNOWLEDGEMENTS}

This work was supported by grants from the Directorate Research and Community Services Ministry of Research Technology and Higher Education Jakarta, Indonesia. As well as from the PMDSU (Program Magister Doktor Sarjana Unggul) (No. 315-12/UN7.5.1/PP/2017). Also the Mobility Grant Under Sandwich-like Program (1930/D3.2/PG/2017) and the Research Center for Chemistry, Indonesian Institute of Sciences (LIPI), South Tangerang, Indonesia.

\section{REFERENCES}

Ahmed S. 2016. Culture, isolation and identification of bacteria from municipal area of soil. Biol Sci 5 (7): 52-54

Allen GR, Steene R. 1999. Indo-Pacific coral reef guide. Tropical Reef Research, Singapore.

Arbi UY. 2011. Aspek biologi dan sistematika nudibranch. Fauna Indonesia 10 (1): 22-29.

Asagabaldan MA, Ayuningrum D, Kristiana R, Sabdono A, Radjasa O K Trianto A. 2017. Identification and antibacterial activity of bacteria isolated from marine sponge Haliclona (Reniera) sp. against multidrug resistant human pathogen. IOP Conf Ser: Earth Environ Sci 55: 012019. DOI: $10.1088 / 1755-1315 / 55 / 1 / 012019$

Ayuningrum D, Kristiana R, Asagabaldan MA, Nuryadi H, Sabdono A Radjasa OK, Trianto A. 2017. Isolation, characterization and antagonistic activity of bacteria symbionts Hardcoral Pavona sp isolated from Panjang Island, Jepara against infectious Multi-Drug Resistant (MDR) Bacteria. IOP Conf Ser: Earth Environ Sci 55 012029. DOI: 10.1088/1755-1315/55/1/012029.

Ayuningrum D, Liu Y, Riyanti, Sibero MT, Kristiana R, Asagabaldan MA, Wuisan ZG, Trianto A, Radjasa OK, Sabdono A, Schäberle TF. 2019. Tunicate-associated bacteria show a great potential for the discovery of antimicrobial compounds. Plos One 14 (3): e0213797. DOI: 10.1371/journal.pone.0213797.

Balouiri M, Sadiki M, Ibnsouda AK. 2016. Methods for in vitro evaluating antimicrobial activity: A review. J Pharm Anal 6: 71-79.

Banawas S, Abdel-Hadi A, Alaidarous M, Alshehri A, Dukhyil AAB, Alsaweed M, Boamer M. 2018. Multidrug-resistant bacteria associated with cell phones of healthcare professionals in selected hospitals in Saudi Arabia. Canadian J Infect Dis Med Microbio 2018: 6598918. DOI: 10.1155/2018/6598918

Basak S, Singh P, Rajurkar M. 2016. Multidrug-resistant and extensively drug-resistant bacteria: A study. J Pathogen 2016: 4065603. DOI: $10.1155 / 2016 / 4065603$

Behrens DW, Terrence MG, Angel V. 2005. Nudibranch behaviour. New World Publications, Inc., Jacksonville, FL., U.S.A.

Böhringer N, Fisch KM, Schillo D, Bara R, Hertzer C, Grein F, Eisenbarth JH, KaligisF, Schneider T, Wägele H, König GM Schäberle TF. 2017. Antimicrobial Potential of Bacteria Associated with Marine Sea Slugs from North Sulawesi, Indonesia. Front Microbiol 8: 1092. DOI: 10.3389/fmicb.2017.01092.

Calvacanti BC, Júnior HVN, Seleghim MHR, Berlinck RGS, Cunha GMA, Moraes MO, Pessoa C. 2008. Cytotoxic and genotoxic effects of tambjamine D, an alkaloid isolated from the nudibranch Tambja eliora, on Chinese hamster lung fibroblasts. Chem Biol Interact 174 155-165.

Chavanich S, Viyakarn V, Sanpanich K, Harris LG. 2013. Diversity and occurrence of nudibranchs in Thailand. Mar Biodiv 43 (1): 31-36.

Christensen A, Martin GDA. 2016. Identification and bioactive potential of marine microorganisms from selected florida coastal areas Microbiol Open 6: 4. DOI: 10.1002/mbo3.448.

Coleman N. 2001. 1001 Nudibranchs: Catalogue of Indo-Pacific Sea Slugs. Neville Coleman's Underwater Geographic Ltd., Springwood, Qld.

Cunha CM, Leandro M, Vieira, Alvaro EM. 2018. Direct observations of the nudibranch Corambe carambola (Marcus, 1955) preying on the bryozoan Alcyonidium hauffi Marcus, 1939. Mar Biodiv 48 (4): 1693 1694.
Davis TR, David H, Stephen DAS. 2018. Responses of Dendronephthya australis to predation by Dermatobranchus sp. nudibranchs. Mar Freshw Res 69 (1): 186-190.

Eisenbarth JH, Undap N, Papu A, Schillo D, Dialao J, Reumschüssel, Kaligis F, Bara R, Scäberle TF, König GM, Yonow N, Wägele. 2018. Marine heterobranchia (Gastropoda, Mollusca) in Bunaken National Park, North Sulawesi, Indonesia-a follow-up diversity study. Diversity 10 (4): 127. DOI: 10.3390/d10040127

Essghaier B, Marie LF, Jean LC, Hajlaoui MR, Boudabous A, Jijakli MH, Najla SZ. 2009. Biological control of grey mould in strawberry fruits by halophilic bacteria. J Appl Microbiol 106 (3): 833-846.

Fedders H, Podschun R, Leippe M. 2010. The antimicrobial peptide CiMAM-A24 is highly active against multidrug-resistant and anaerobic bacteria pathogenic for humans. Intl J Antimicrob Agents 36: 264266.

Fehér D, Barlow RS, Lorenzo PS, Hemscheidt TK. 2008. A 2-Substituted Prodiginine, 2-(p-Hydroxybenzyl) prodigiosin, from Pseudoalteromonas rubra. J Nat Prod 71: 1970-1972.

Garibyan L, Avashia N. 2013. Research techniques made simple: Polymerase Chain Reaction (PCR). J Invest Dermatol 133 (3): 1-8.

Gupta A, Sao S, Kataria R, Jain Y. 2017. Isolation, identification and characterisation ofantibiotic-producingg bacteria from soil at Dr. CV Raman University Campus Bilaspur (C.G.). World J Pharmaceut Res 6 (8): 1004-1011.

Harris LG, 1973. Nudibranch Associations. Vol. 2. Academic Press, Inc., New York.

He WF, Li Y, Feng MT, Gavagnin M, Mollo E, Mao SC, Guo YW. 2014. New isoquinolinequinone alkaloids from the South China Sea nudibranch Jorunna funebris and its possible sponge-prey Xestospongia sp. Fitoterapia 96: 109-114.

Hentschel U, Schmid M, Wagner M, Fieseler L, Gernert C, Hacker J. 2001. Isolation and phylogenetic analysis of bacteria with antimicrobial activities from the Mediterranean sponges Aplysina aerophoba and Aplysina cavernicola. FEMS Microbiol Ecol 35: 305312.

Hooper JNA. 2003. Sponguide: Guide to sponge collection and identification, version 2003. Queensland Museum, Australia

Huong PTM, Phong NV, Thao NP1, Binh PT, Thao DT, Thanh NV, Cuong NX, Nam NH, Thung DC, Minh CV. 2019. Dendrodoristerol, a cytotoxic C20 steroid from the Vietnamese nudibranch mollusk Dendrodoris fumata J Asian Nat Prod Res. 2019: 1-8. DOI: 10.1080/10286020.2018.1543280.

Isnansetyo A, Kamei Y. 2003. Pseudoalteromonas phenolica sp. nov., a novel marine bacterium that produces phenolic anti-methicillinresistant Staphylococcus aureus substances. Intl J Syst Evol Microbiol 53: 583-588.

Jassbi AR, Younes M, Omidreza F, Jima NC, Bernd S. 2016. Bioassay guided purification of cytotoxic natural products from a red alga Dichotomaria obtusata. Brazilian J Pharmacogn 26: 705-709.

Johnson RF, Gosliner TM. Traditional taxonomic groupings mask evolutionary history: A molecular phylogeny and new classification of the Chromodorid nudibranchs. PLoS ONE 7(4): e33479. DOI: 10.1371/journal.pone.0033479

Kamei Y, Isnansetyo A. 2003. Lysis of methicillin-resistant Staphylococcus aureus by 2, 4diacetyl phloroglucinoll produced by Pseudomonas sp. AMSN isolated from a marine alga. Intl J Antimicrob Agents. 21 (1): 71-74

Kang DW, Kyung JL, Chung JS. 2013. Two new marine sponges of the genus Haliclona (Haplosclerida: Chalinidae) from Korea. Anim Syst Evol Divers 29: 51-55.

Korshunova T, Martynov A, Bakken T, Picton B. 2017. External diversity is restrained by internal conservatism: New nudibranch mollusk contributes to the cryptic species problem. Zoologica Scripta 46 (6): 683-692.

Kristiana R, Ayuningrum D, Asagabaldan MA, Nuryadi H, Sabdono A, Radjasa OK, Trianto A. 2017. Isolation and partial characterization of bacteria activity associated with gorgonian Euplexaura sp. against methicillin-resistant Staphylococcus aureus (MRSA). IOP Conf Ser: Earth Environ Sci 55: 012056. DOI: 10.1088/1755-1315/55/1/012056

Kristiana R, Diah A, Meezan AA, H. Nuryadi, Agus S, Ocky KR, Agus T. $1-6$

Leal MC, Sheridan C, Osinga R, Dionisio G, Rocha RJM, Silva B, Rosa R, Calado R. 2014. Marine microorganism-invertebrate assemblages: 
Perspectives to solve the "Supply Problem" in the initial steps of drug discovery. Mar Drugs 12 (7): 3929-3952.

Lee AS, Lencastre H, Garau J, Kluytmans J, Kumar SM, Peschel A, Harbarth S. 2018. Methicillin resistance Staphylococcus aureus. Nat Rev Dis Primers 4: 18033. DOI: 10.1038/nrdp.2018.33.

Magiorakos AP, Srinivasan A, Carey RB, Carmeli Y, Falagas ME, Giske CG, Harbarth S, Hindler JF, Kahlmeter G, Olsson-Liljequist B, Paterson DL, Rice LB, Stelling J, Struelens MJ, Vatopoulos A, Weber JT, Monnet DL. 2012. Multidrug-resistant, extensively drug-resistant and pandrug-resistant bacteria: an international expert proposal for interim standard definitions for acquired resistance. Clin Microbiol Infect 18 (3): 268-281.

Martynov AV, Korshunova TA. 2012.Opisthobranchh mollucs of Vietnam (Gastropoda:Opisthobranchiaa). Benthic fauna of Bay of Nhatrang Southern Vietnam. Vol 2. KMK Scientific Press Ltd. Moscow

Mehbub MF, Lei J, Franco C, Zhang W. 2014.Marine spongee-derived natural products between 2001 and 2010: trends and opportunities for discovery of bioactives. Mar Drugs 12 (8): 4539-4577.

Mehravar M, S. Sardari, P. Owlia. 2010. Screening of membrane active antimicrobial metabolites produced by soil actinomycetes using membrane models. J Paramed Sci 1 (4): 18-25.

Miller JH, Jessica JF, Arun K, Jeremy GO, A. Jonathan S, Peter TN. 2018. Marine invertebrate natural products that target microtubules. J Nat Prod 81 (3): 691-702.

Muhialdin BJ, Hassan Z, Imdakin MMA, Kahar FKSA, Aween MM 2012. Malaysian isolates of lactic acid bacteria with antibacteria activity against gram-positive and gram-negative pathogenic bacteria. J Food Res 1 (1): 110-116.

Mulyadi HA. 2011. Predominant zooplankton and its correlation to chlorophyll-A around coastal water of Nusalaut Island, Maluku. Oseanologi dan Limnologi di Indonesia 37 (3): 415-433.

Panghal M, Singh K, Kadyan S, Chaudary U, Yadav JP. 2015. The analysis of distribution ofmultidrug-resistantt Pseudomonas and Bacillus species from burn patients and burn ward environment. Burns 41: 812-819.

Radjasa OK, Sabdono A. 2003. Screening of secondary metaboliteproducing bacteria associated with corals using $16 \mathrm{~S}$ rDNA-based approach. J Coast Develop 7: 11-19.

Ramirez, Maria CA, David EW, Juliana RG, Lizbeth LL, Parra, Mario FC, Santos, Daiane D, Ferreira, Juliana T, Mesquita, Andre G, Tempone, Antonio GF, Vinícius P, Eduardo H, Raymond JA, Roberto GSB 2017. Rearranged terpenoids from the marine sponge Darwinella $\mathrm{cf}$ oxeata and its predator, the nudibranch Felimida grahami. J Nat Prod 80 (3): 720-725.

Ramos JL. 2004. Pseudomonas. Kluwer Academic/Plenum Publishers, New York.

Risan MH. 2017. Isolation and identification of bacteria from under fingernails. Intl J Curr Microbiol Appl Sci 6 (8): 3584-3590.

Riyanti, Jaka W, Ocky KR. 2009. Isolation and screening of antimicrobial producing-actinomycetes symbionts in nudibranch. Indonesian $\mathrm{J}$ Biotechnol 14 (1): 1132-38.

Sadhasivam G, Muthuvel A, Vitthal WM, Pachaiyappan A, Kumar M, Thangavel B. 2013. In vitro antibacterial, alpha-amylase inhibition potential of three nudibranchs extractsfrom southeastt coast of India. J Coast Life Med 1 (3): 186-192.

Scheuerman O, Schechner V, Carmeli Y, Gutiérrez-Gutiérrez B, Calbo E, Almirante B, Viale PL, Oliver A, Ruiz-Garbajosa P, Gasch O, Gozalo
M, Pitout J, Akova M, Pena C, Molina J, Hernández-Torres A, Venditti M, Prim N, Origüen J, Bou G, Tacconelli E, Tumbarello M, Hamprecht A, Karaiskos I, de la Calle C, Pérez F, Schwaber MJ, Bermejo J, Lowman W, Hsueh PR, San Francisco CN, Bonomo RA, Paterson DL, Pascual A, Rodríguez-Baño J. 2018. Comparison of predictors and mortality between bloodstream infections caused by ESBL-producing Escherichia coli and ESBL-producing Klebsiella pneumoniae. Infect Contr Hospital Epidemiol 39 (6): 660-667.

Schinke C, Thamires M, Sonia CN, Queiroz, Itamar S, Melo, Felix GR, Reyes. 2017. Antibacterial compounds from marine bacteria. 20102015. J Nat Prod 80: 1215-1228.

Schuett C, Hilke D. 2013. Endobacterial morphotypes in nudibranch cerata tips: A SEM analysis. Helgoland Mar Res 67 (2): 219-27.

Senthilkumar K, Se-Kwon K. 2013. Marine invertebrate natural products for anti-inflammatory and chronic diseases. Evid-Based Compl Altern Med 2013: 1-10.

Sibero MT, Bachtiarini TU, Trianto A, Lupita AH, Sari DP, Igarashi Y, Harunari E, Sharma AR, Radjasa OK. Sabdono A. 2019a. Characterization of a yellow pigmented coral-associated bacterium exhibiting anti-bacterial activity againstMultidrug-Resistantt (MDR) Organism. Egyptian J Aquat Res 45 (1): 81-87.

Sibero MT, Sabdaningsih A, Radjasa OK, Sabdono A, Trianto A, Subagiyo. 2019b. Karakterisasi senyawa bioaktif kapang laut trichoderma asperellum mt02 dengan aktivitas anti-extended spectrum $\beta$-Lactamase (ESBL) E . coli. Jurnal Kelautan Tropis 22 (1): 9-18.

Sibero MT, Sahara R, Syafiqoh N, Tarman K. 2017. Antibacterial activity of red pigment isolated from coastal endophytic fungi against multidrug resistant bacteria. Biotropia 24 (2): 161-172.

Sidharta BR. 2000. Pengantar Mikrobiologi Kelautan. Universitas Atmajaya, Yogyakarta. [Indonesian]

Sim DCM, Mudianta IW, White AM, Martiningsih NW, Loh JJM, Cheney KL, Garson MJ. 2017. New sesquiterpenoid isonitriles from three species ofphyllidiidd nudibranchs. Fitoterapia 126: 69-73.

Sinsuwan S, Sureelak R, Jirawat Y. 2010. A NaCl-stable serine proteinase from Virgibacillus sp. SK33 isolated from Thai fish sauce. Food Chem 119 (2): 573-579.

Tarman K, Safitri D, Setyaningsih I. 2013. Endophytic fungi isolated fromRhizophoraa mucronata and their antibacterial activity.Squalenen Bull Mar Fisher Postharvest Biotechnol 8 (2): 69-76.

Vlachou P, Le Goff G, Alonso C, Álvarez PA, Gallard JF, Fokialakis N, Ouazzani J. 2018. Innovative approach to sustainable marine invertebrate chemistry and a scale-up technology for open marine ecosystems. Mar Drugs 16 (5): 152. DOI: 10.3390/md16050152

Walsh PS, Metzger DA, Higuchi R. 1991. Chelex 100 as a medium for simple extraction of DNA for PCR-based typing from forensic material.BioTechniquess 10 (4): 506-513.

Wang TZ, Kodiyanplakkal RPL, Calfee DP. 2019. Antimicrobial resistance in nephrology. Nature Rev Nephrol. DOI: 10.1038/s41581019-0150-7

Wu Q, Chen WT, Li SW, Ye JY, Huan XJ, Gavagnin M, Yao LG, Wang H, Miao ZH, Li XW, Guo YW.. 2019. Cytotoxic nitrogenous terpenoids from two south china sea nudibranchs Phyllidiella pustulosa, Phyllidia coelestis, and their sponge-prey acanthella cavernosa. Mar Drugs 17: 23-27.

Zhukova NV, Eliseikina MG. 2012. Symbiotic bacteria in the nudibranch mollusk Dendrodoris nigra: fatty acid composition and ultrastructure analysis. Mar Biol 159: 1783-1794. 